\title{
The retailer brands personality: A scale development in a Tunisian context
}

\author{
Dr Maryem Trabelsi ${ }^{1}$ \\ Dr Hawaa. A. B.Saad Allah" ${ }^{* 2}$ \\ Dr Balsam.S.A.Hussien ${ }^{3}$ \\ ${ }^{1,2,3}$ Al Jouf University. Kingdom of Saudi Arabia
}

This journal is licensed under a Creative Commons Attribution-NonCommercial 4.0 International License (CC-BY-NC). Articles can be read and shared for noncommercial purposes under the following conditions:

- BY: Attribution must be given to the original source (Attribution)

- NC: Works may not be used for commercial purposes (Noncommercial)

This license lets others remix, tweak, and build upon your work non-commercially, and although their new works must also acknowledge you and be non-commercial, they don't have to license their derivative works on the same terms. License Deed Link: http://creativecommons.org/licenses/by-nc/4.0/

Legal Code Link: http://creativecommons.org/licenses/by-nc/4.0/legalcode

$A B C$ Research Alert uses the CC BY-NC to protect the author's work from misuse.

\begin{abstract}
of recent interest in consumer behavior research and retailing branding is the consumer's use of retailer brands that increases over time. Starting from the set of unique characteristics that those brands do own, this study sheds light on an uncovered area relating to their perception and their mental positioning and presents hence a measure of their perceived personality in the Tunisian context. Despite the big number of scales that were developed to measure brand personality, yet no research has focused on the retailer brands personality. To fill in this gap, a set of interviews was administrated, and then evidence for the scale's reliability was presented thanks to a series of statistical analyses.
\end{abstract}

\section{Keywords}

Retailer brands, brand personality, retailing branding

\section{Résumé}

Il s'agit dans cette recherche de développer une échelle de mesure de la personnalité des marques de distributeurs spécifique au contexte tunisien. L'objectif de cette recherche est justifié en quelques sortes par les propriétés distinctives de ces marques, des sources d'inférences de leurs personnalités qui se distinguent pleinement de celles des marques nationales et enfin par les limites de transposition des échelles de personnalité développées dans des contextes culturels différents de le notre. Tout d'abord et grâce à une recherche qualitative, un beau nombre de qualificatifs ont été générés puis des séries d'analyses statistiques de purification, de confirmation et d'évaluation de la fiabilité de l'échelle ont eu lieu.

Mots clés :

marques de distributeurs, personnalité de la marque, contexte tunisien

\section{INTRODUCTION}

The relationship between consumers and brands is more than a possession of an object or a product that has only an utilitarian function allowing the satisfaction of a material need (Gilmore, 1919; Ambroise, 2006; Kapferer, 2001). In fact, when walking across a store and among many brands, the customers choose the brand that is close to them in all its characteristics, a brand full of symbols and signs (Venkatesh, 1999). The experience of 
buying is indeed a quest of the self (Belk, 1988). Through this research, the brand anthropomorphisation was the focal point, all the attention was paid to the brand world and how a simple name engraved on a packaging lost its original function as a "Differentiation tool" and has been projected in a symbolic world. Moreover, nowadays the brand is unconsciously imbued with personality traits and considered as a human being, a partner or even a close friend, thus enabling the satisfaction of diverse relational and psychological needs in addition to the biological ones. In fact, the brand seems to be the spokesperson of its users; it communicates and conveys messages on their behalf. In this study, we extended this line of research to the case of an important commercial object namely the retailer brands or the Private labels. More precisely, the main goal is to develop a scale for measuring retailer brands personality and to assess its psychometric properties. The focus on those brands is motivated by their uniqueness and distinctive features that will be presented later on.

\section{BRAND PERSONALITY: ORIGINS AND TRANSPOSITION TO THE BRANDS WORLD}

\section{Personality in psychology: Return to the roots}

Personality is an extremely ancient concept that finds its roots in psychology and dates back to the antiquity. Despite all the attempts to clarify it, the concept of personality escapes every restriction and its nature is still polemic. The early theories of Empedocles and Hippocrates claimed the existence of a strong relationship between personality and the body chemistry (blood, black bile, yellow bile and phlegm).

Since then, more structured theories appeared especially in the beginning of the $20^{\text {th }}$ century perhaps the most important and influential one is the psychoanalytic theory presented by Freud $^{1}$ and then developed by his disciples. According to the bellwether of psychoanalysis, personality is the result of the continuous interaction and even conflict between three components of the human psyche (the id, the superego and the ego), thus, personality is considered to be dynamic, cumulative, stable and durable over time. Moreover and similarly to the stages of physiological development (fetal, childhood, puberty, adulthood and senescence), according to Freud (1923), the personality formation must go through by predetermined stages of evolvement (the oral stage, the anal, the phallic, the repressive era and the genetic stage). However, Freud's emphasis on biological and psychosexual motives in personality development has been widely criticized by many psychologists; thus, other theories came to light showing the existence of additional determinants of human personality.

Aside from the personality drivers' debate, a different wave of research has focused on the measure of this concept and generated hence a number of personality scales (Allport and Odbert, 1936; Goldberg, 1976) that provided diverse ones, however, the well-known one is the OCEAN composed of five dimensions which are openness, conscientiousness, extraversion, agreeableness and neuroticism.

\section{The concept of personality in marketing}

The transposition of the personality concept to marketing started by a stream of research focusing on the analysis and the conceptualization of human personality and to which extent it influences the consumers' choices and decision making process in general. Later, the 
concept was transposed to brands especially by marketing practitioners and advertisers in USA. Its emergence in the marketing theory dates back to 1958 when Martineau (1958, p144) defined it as "all the non material cues of a product" that are able to distinguish the latter from its competitors in the consumers' eyes. Then, efforts were multiplied to define it as "the set of symbolic attributes" (Plummer, 1984), "the character of a brand" (Seguela, 1982), the materialization of the brand image using words generally attributed to human beings (Keller, 1993). In 1997, in a study devoted totally to brand personality concept, Aaker (1997) defined it as "the set of human characteristics associated with a brand". Despite its fame, this definition was extremely criticized, for instance, Ambroise et al (2006) claimed that the main weakness of the definition is that it comprises some traits that are exclusive to brands and have no equivalent in human personality, thus, they presented an alternative one considering brand personality as "the set of traits of human personality associated with a brand", a definition that helps consumers projecting their own traits on the brand since all the non-common features between brand personality and the human one have been excluded.

Another critique was presented by Kapferer (2003, p151) who defines brand personality as "the set of human personality traits that are both applicable and relevant for brands", the critique addressed to the Aaker's (1997) definition is that the latter uses the term "characteristics" rather than "traits" which includes several human features that don't refer at all to personality like the physical features, the inner values, the age and the gender...

\section{The brand personality: The measurement}

Since its emergence in the world of consumer behavior research, brand personality has attracted a lot of interest and numerous studies have been undertaken to examine its relationship with other concepts as brand loyalty, brand trust, brand preference and brand usage. The main problem was the absence of a reliable and valid scale.

However, this gap didn't prevent numerous scholars from conducting their research, some have used ad hoc scales which are atheoritical in nature and were developed especially for the purposes of the study in question and its specific needs, they comprised a set of traits chosen arbitrarily ranging from 20 to 300. Although their usefulness and utility, those scales suffered from sundry limits. In fact, they were neither reliable nor valid, besides, they embodied a high probability of omitting or missing the key traits.

Another wave of researchers (Bellenger, Steinberg, and Stanton 1976; Dolich 1969; Guido, Kaprara and Barbaranelli,2002) and in order to overcome the drawbacks of the ad hoc scales, opted for the use of more theoretical scales taken from psychology either without or with little adjustments which affected also the research findings as many human personality traits can not be mirrored in brands.

Given the scales validity problem and the questionable previous studies findings and motivated by Kassarjian's advice (1971, p415) who claimed that "if unequivocal results are to emerge [in the literature on the symbolic use of brands] consumer behavior researchers must develop their own definitions and design their own instruments to measure the personality variables that go into the purchase decision", Aaker (1997) developed a framework of brand personality dimensions based on a hierarchical approach similar to that used in psychology. Hence and in a first stage, brand personality traits were gathered from various sources namely human psychology scales (especially the Big Five model), 
personality scales used by academics and practitioners (Alt and Griggs 1988; Batra, Lehmann and Singh 1993; Levy 1959; Malhorta 1981; Plummer 1985; Wells et al.1957) and finally a qualitative research (a free association-task was proposed to respondents who were asked to write down the traits of two brands belonging to diverse product categories; symbolic, utilitarian and both symbolic and utilitarian; Ratchford 1987). After a purification process, a reliable and valid scale composed of five dimensions sincerity, excitement, competence, sophistication and ruggedness and 42 items was generated.

Despite its new insights to BP, Aaker's BPI scale was criticized. The first wave of critiques was related to the lack of its external validity. Indeed, empirical studies didn't bring support for Aaler's scale in different cultural contexts (Ferrandi et al, 1999; O'Cass and Lim, 2001; Supphellen and Gronhaug, 2003; Magin et al, 2003...)

The second stream of critiques started from the Churchill's paradigm (1979) in which he considered the ultimate way to get reliable and valid scales is the development of a pure and clear definition. A definition where all that don't belong to the construct in hand and that "...need to be kept separate both on theoretical grounds and for practice use" must be rejected. Kapferer (2003) wondered if the BP scales do really measure BP, his answer was not, for instance, the Aaker's BPI measures besides the personality other concepts like brand identity, product performance, demographic characteristics like gender, age and class as well as intellectual abilities, this weakness is due to a certain extent to the traits' generation sources especially practitioners BP scales.

To overcome the BPI's weaknesses, many substitutes following different methods were generated. For instance, Ambroise (2006) opted for the construction of a BP scale based exclusively on the consumers' brand perceptions through a qualitative research without importing any descriptors from the human personality scales. As a result, the research gave birth to a new instrument called the "Brand personality barometer" that embraces five dimensions which are; introversion; agreeableness comprising three facets conviviality, creativity and appeal; conscientious character; sophistication with two facets originality and preciosity and finally fallacious character that encompasses two facets deceitful and ascending.

\section{RESEARCH METHODOLOGY AND RESULTS}

The subject under study is somewhat new since no previous research focused on the personality traits of RB. Thus, the current research is subscribed in a discovery context (Nyeck; Bergadâa et Nyeck, 1992) and a qualitative approach seems to be the most appropriate in order to examine the specificities of Private Labels in Tunisia. The study comprised three steps. First, we generated a list of personality items on the basis of individual interviews with Tunisian shoppers. Second, a survey with 230 adult consumers was undertaken in order to eliminate inappropriate items and get a most parsimonious list of retailer brands personality traits. Finally, purification and confirmation analyses through SPSS 17 and AMOS18 were done in order to sort out personality dimensions and then confirm the stability as well as the reliability of the scale with respect to each personality dimensions.

\section{First step: The items generation}

As it was discussed earlier, it's obvious that the Aaker's scale (1997) suffers from several weaknesses mainly when applied to non American context. Those limits led many scholars to 
leave the "imposed etic" approach that consists in reproducing an imported scale either without modifications or with a simple translation to the local language (Enriquez, 1979) and use other approaches to develop scales that take into consideration the particularities of their countries, cultures and the nature as well as the depth of the relationships that customers do have with brands.

In our study, the "emic-etic" approach was chosen thanks to its numerous advantages and the specificities of Tunisian consumers as well as the retailer brands features. First, those brands have been recently broadcasted; hence, the transposition of a BP scale developed among well-known brands that have a high notoriety rate may baize the research findings. Second, as no research has been undertaken on RBP on one hand and in view of their particularities on the other hand, the study follows a discovery process concerning consumers' perceptions of those brands.

Retailer brands or private labels are conventionally defined as all those "brands that belong to a commercial company specialized in whole or retail sale and are sold exclusively by this corporation or under its control" or also "(...) the product (s) which all their characteristics were defined by the company or the group of companies that broadcast and sell them and are the owner of the brand that they are sold under its name". Those brands have many distinctive characteristics that put them in a different register compared to the national ones. First, since they are exclusively sold at the retailers' sales points, a strong relationship has been demonstrated in several studies between the stores' credibility, image and reputation as well as other store equity dimensions and the private labels ones (Corstjens and Lal 1996/2000; Dabija 2011...), hence their characteristics, price strategy as well as their quality should be well studied in order to avoid any negative impact on the store's image. Second, on the contrary to national brands, retailer ones do not demand huge communication budget which not only decreases their variable cost and betters therefore the store's profit margins but limits the media role in their personality development and perception. Third, it was advanced by some researchers that the information sources that are usually used to imbue a brand with personality traits are not the same when dealing with private labels' one (Astou and Lévesque 2001; Capelli and Pantin-Sohier 2003). Finally, on the contrary to what is conventionally known about retailer brands as being cheap, a little bit innovative, having a low or average-quality and produced mainly to satisfy the needs of a price sensitive segment, the recent literature see them as real substitutes for national brands thanks to their acceptable and even superior quality.

The following table highlights the main differences between retailer brands and the national ones:

\begin{tabular}{|l|l|l|}
\hline Characteristics & National Brands & Retailer Brands \\
\hline Advertisement & Strong (TV, Newspapers, leaflets) & Weak (Stores, local prospectus) \\
\hline Quality & Judged high & Judged average \\
\hline Risk linked to quality & Judged weak & Judged average or high (for some products) \\
\hline Price & Judged high & Judged average \\
\hline Packaging & Sophisticated & Average or classic \\
\hline Innovation & High & Weak \\
\hline \multicolumn{2}{|l}{ Table 1: RB versus NB (Source: Bergès-Sennou) } \\
\hline
\end{tabular}

\section{OBJECTIVES AND QUALITATIVE RESEARCH QUESTIONS:}

The main questions that were addressed in the interview guide were related to the study objectives. In fact, after having inquired about RB in general (the consumed ones, their product categories...), 
respondents were asked to "Imagine that brand X (retailer or national brand) was a human being" and "Tell what kind of person X would be". Once the respondents gave deliberately the maximum of features, a list of the different traits generated by former scales (Aaker, 1997; Gouteron, 2006; Ambroise, 2006; Smaoui, 2006) was presented to them in order to choose additional descriptors. Hence, a pool of items was built up.

The following table hands out the main purposes of the study as well as the research's questions:

\begin{tabular}{|l|l|}
\hline Objectives & Research questions \\
\hline $\begin{array}{l}\text { Assessing private labels' } \\
\text { notoriety and acquisition } \\
\text { rate }\end{array}$ & $\begin{array}{l}\text { Do you know the Private Labels (Brands n }{ }^{\circ} \text { 1)? } \\
\text { Could you cite some of the ones you know? } \\
\text { In which product categories did you observe and remark them? } \\
\text { Did you purchase and consume one of them? }\end{array}$ \\
\hline Private Labels' personality & $\begin{array}{l}\text { Imagine that the retailer brand that you have just mentioned was a } \\
\text { human being, what kind of person it would be? In other terms, } \\
\text { what would its personality traits be, how could you describe it as if } \\
\text { it was a person? }\end{array}$ \\
\hline
\end{tabular}

\section{DATA COLLECTION, SAMPLING AND CONTENT ANALYSIS}

To achieve the study objectives, an individual interview deemed more appropriate. Indeed, this approach provides more reliable answers as respondents are not influenced by other participants' opinions as well as the generation of more detailed information. Moreover, it allows to sound in depth the opinions, the attitudes and motivations of the respondent and to collect data in locations where it is impossible to gather a group. Thus, 15 interviews of an approximately duration of fifteen minutes each were administered. It seems crucial to notice that the interviewer's neutrality was maintained during the interviews to assure that their opinion did not influence the asked person's one. Concerning the sample, it was chosen in a way that it becomes representative of the treated problem or of the different situations (Nyeck, 2000). Therefore, it was judged important to opt for so diverse social classes and age brackets in order to have a variety in perceptions and experiences. The sample is composed of fifteen customers, eleven women and four men, who were interviewed either where they were browsing in the stores (Champion, Carrefour market, Carrefour and Géant) to benefit from in-store advantages or at universities (ISG and IHEC) to benefit in this case from the students' innovativeness, and their early adoption of new ideas, products, lifestyles, haircuts and definitely brands as well as their unceasingly search of differentiation and uniqueness through branded products (the sociodemographic characteristics of the interviewees are presented in Annex 1)

Finally and in regard to the content analysis, first, the fifteen interviews were entirely transcribed. Every word, non-verbal communication and interviewees' questions were hence taken into consideration during this step. Once the corpus is completed and all the interviews were fully transcribed, it was opted for a lexical analysis that consists in picking up the words relating to the studied concept which is in this case brand personality. Thus, 64 traits were generated and are to be used later on in the scale purification stage (see Annex 2).

\section{The second step : The scale's purification The sample and the questionnaire design:}

The management of a heavy list composed of sixty four candidate traits seems to be so hard and a source of bias in posterior use of the scale. Hence and in order to get a parsimonious list of brand personality traits, 230 respondents at different sales points were asked to administrate their opinions about retailer brands personality. All the responses were recorded via a five-point Likert type format with endpoints of strongly disagree (1) and strongly agree (5). 


\section{The exploratory analysis:}

The collected data was firstly seized and analyzed through a Principal Component Analysis (SPSS 17) in order to gather the diverse candidate personality traits and classify them under different dimensions. Then, the reliability of the scale was assessed through the Cronbach's Alpha. The result was a multidimensional scale composed of four factors presented in the following table. Compared to the existing measurement instruments relating to brand personality in general, the generated RBP scale contains less factors.

\begin{tabular}{|c|c|c|c|c|}
\hline Items & Excitation & Agreeableness & Originality & $\begin{array}{l}\text { Fallacious } \\
\text { Character }\end{array}$ \\
\hline Beautiful & 0.796 & & & \\
\hline Cute & 0.682 & & & \\
\hline Young & 0.671 & & & \\
\hline Adorable & 0.639 & & & \\
\hline Sympathetic & 0.588 & & & \\
\hline Pretty & 0.582 & & & \\
\hline Relaxing & 0.574 & & & \\
\hline Optimist & 0.521 & & & \\
\hline Cheerful & & 0.783 & & \\
\hline Happy & & 0.742 & & \\
\hline Smiling & & 0.734 & & \\
\hline Charming & & 0.662 & & \\
\hline Tender & & 0.603 & & \\
\hline Original & & & 0.796 & \\
\hline Innovative & & & 0.695 & \\
\hline Modern & & & 0.593 & \\
\hline Deceitful & & & & 0.836 \\
\hline Incompetent & & & & 0.658 \\
\hline Liar & & & & 0.645 \\
\hline EigenValue & 7.962 & 1.735 & 1.507 & 1.310 \\
\hline$\%$ variance & 34.618 & 7.542 & 6.553 & 5.696 \\
\hline Cronbach' $\alpha$ & 0.879 & 0.846 & 0.707 & 0.610 \\
\hline KMO & 0.839 & & & \\
\hline
\end{tabular}

Despite the difference in factors' number, the obtained structure presents some similarities with the scales that were developed elsewhere in the world. It holds back a dimension of the pioneer BP scale constructed by Aaker (1997) in the American context which is excitation with eight items. Concerning the three other factors; fallacious character, agreeableness and originality, they are almost similar to those generated by Ambroise (2007) in a French context with a mere difference that originality is not a dimension but a facet of "Sophistication".

\section{The third step: The scale's structure confirmation}

After having generated the first structure of the RBP scale and assessed its reliability and in order to examine more rigorously the robustness of its dimensionality, a confirmatory factor analysis was applied. This approach has the merit that it manages the item pool in order to improve the fit of the measurement model by eliminating the items that represent T-Student or Critical Ratio values inferior to the absolute magnitude of 1.96 .

The application of the Confirmatory Factor Analysis (CFA) on the structure of the RBP scale that is composed of 19 items furnished a bad and unsatisfactory adjustment quality. In fact, the items original, relaxing, liar, deceiving and incompetent presented poor T-Student (inferior to 1.96 ) and small $\mathrm{R}^{2}$ values. Their retirement one by one ameliorated systematically the overall adjustment quality. In fact, almost all the absolute indices presented good values 
reaching the desired theoretical values $(\mathrm{GFI}=0.901$; $\mathrm{AGFI}=0.855)$. The same thing was observed for both the Incremental Indices that reached 0.9 (CFI=0.969; TLI=0.961) and the Parsimony Indices (Normed X2=1.304). Concerning the items, they have all presented a Critical Ratio that surpasses 1.96 which means that they are all significant, thus, the final RBP scale is composed of 14 items and 3 dimensions (see Annex 3/4).

\begin{tabular}{|l|l|l|l|l|l|l|}
\hline Normed X2 & GFI & AGFI & CFI & RMSEA & TLI & IFI \\
\hline 1.304 & 0.901 & 0.855 & 0.969 & 0.052 & 0.961 & 0.970 \\
\hline \multicolumn{7}{|c|}{ Table 4: The main results of the CFA }
\end{tabular}

In summary, the results of the confirmatory analysis relying on 230 subjects and 14 markers demonstrate that the framework of the retailer brands personality as represented by 14 items and three dimensions is reliable, valid and generalizable.

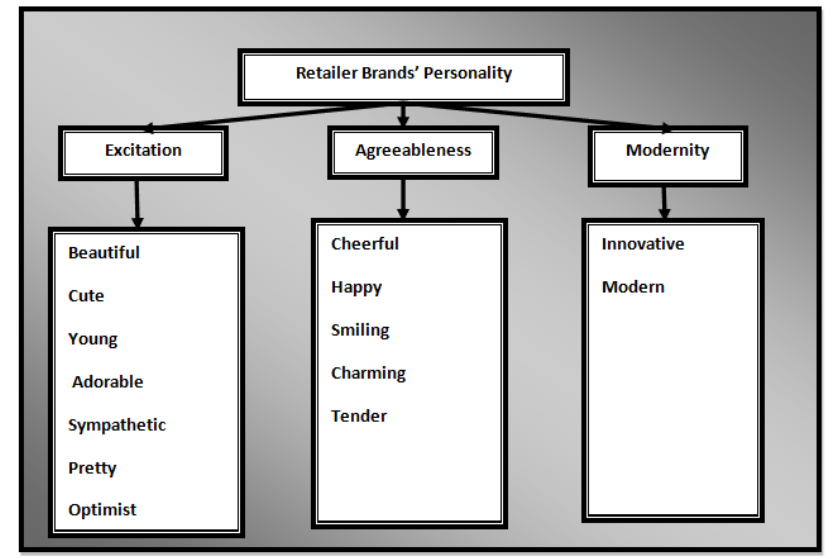

Figure 1: The RB personality scale

\section{DISCUSSION, IMPLICATIONS AND FURTHER RESEARCH}

The review of the marketing literature revealed a gap relating to the personification of the Retailer brands that their investigation was limited in studies of quality, consumer's profile and their impact on the store loyalty. Despite their importance, their excessive presence in hypermarkets all over the world, their special and exclusive characteristics, they were not been subject to studies of personification, thus the present research tried to shed some light at this ignored area.

Hence, a scale of retailer brands personality was developed. The generated measurement instrument consists of fourteen items and three factors (excitation, agreeableness and modernity). By means of purification and confirmation analyses, the sixty-four markers that were generated through the qualitative research gave rise to a more parsimonious list composed of only fourteen items. Despite its exploratory aspect, the scale in hand promises to be a practical instrument for branding research and is important for both academics and practitioners.

Concerning its theoretical implications, first of all the particularity of this research is that it used a concept taken from psychology and transposed it to the brands' world and more precisely to the domain of retailer brands in the Tunisian context. Compared to the brand personality scales that were developed in earlier studies, this scale highlights the singularity of retailer brands in terms of personality perception. In fact, the structure of the RBP scale is clearly different and distinctive from the other scales in terms of dimensions and items' numbers, it deviates from the Big Five and others scales and contains less facets which 
legitimates the development of a scale relating exclusively to those brands. Moreover, the choice of brands that are not well known as the national ones gives room to more realistic items generation and brand's descriptions that encompasses even some negative assessments (items like liar, dishonest...). Finally, the brand personality concept is of an undeniable importance; its study from several researchers' viewpoint requires the generation of a scale that respects the particularities of the country where the research is to be undertaken and the consumers' culture. This point of view calls for the avoidance of the blindly transposition of measurement instruments that are imported and more suitable to other contexts. Hence, the scale generated in the current research is so useful and important for those who intend to examine the Distributor Brands' Personality in Tunisia.

Apropos the managerial benefits, there are numerous advantages. First, the knowledge of the perceived brand's personality is a vital piece of information that helps the managers know the distinctive points of their strategic weapons (brands) and hence maintain or strengthen them as well as their weaknesses that must be overcame. Second, given the small number of items, the Distributor brands' managers become hence able to assess easily the perceived personality of their brands, to adjust their positioning strategy, to draw closer the input facet of brand personality to the perceived or the out-take one (Plummer, 1985) and to monitor changes in perception over time (Astou and Lévesque, 2001; Smaoui, 2008). Finally, the retailer brands' managers can use the generated personality scale to know the personality of every broadcasted brand and use the results in their advertising campaign. Thus, their future advertising axe won't be grounded on the mere advantageous quality/price ratio or the attractive cost-benefit one but on more realistic and reliable information taken directly from the customers.

However this study is not without limitations; those pitfalls are of two types, while some of them were imposed by the field under study, the chosen brands and their notoriety level, others lean on the researcher's deliberate choices that after the end of the empirical analyses turned out that they should be done differently. First, during the qualitative research that aimed the construction of a retailer brands' personality scale, the brand personification seemed to the majority of interviewees a strange topic and sometimes ironic that they tried to botch. Moreover, compared to well known brands, retailer ones stimulated less the imaginary of participants. To remedy this problem, a list comprising the main traits that were generated from prior researches was presented when needed to respondents to help them comprehend the demanded task. This problem persisted also during the quantitative stage and manifested by the existence of compartments left empty in the questionnaires. Second, the precocity of the Distributor Brands' Personality investigation gave room to other problems during the survey.

In fact, many people do ignore the existence of those brands; others were ready and better prepared to give their opinions about their quality, their packaging as well as expressing and showing their satisfaction levels. Third, the research took place in Tunis, Ben Arous and Ariana which means a limited area which could bias the outputs and prevent their extrapolation to the whole Tunisian population. Four, the final stage of the empirical or the survey took place in the hypermarkets (Carrefour, Géant, and Champion) which could influence the respondents' answers who were shopping and had not much time to devote to questionnaires especially about new brands that they do not know very well. Finally, it would be also better to increase the sample and follow a more probabilistic sampling method. 
Finally, this research opens the door for posterior and subsequent researches. First, a fruitful avenue for future research is to examine the role of retailer brands personality in developing a consumer-brand relationship. Second, the knowledge of the brand personality consequences and ability to stimulate, create and develop a brand-customer relationship is vital and important but the knowledge of the factors and reasons that influence the brand anthropomorphization is of a huge importance too. By knowing the motives that let the customer look at a brand as a human being, the managers become able to manipulate them and hence tinning the gap between the intended personality and the effective one.

\section{References}

Aaker, J.L. (1997): "Dimensions of brand personality", Journal of Marketing Research, Vol. 34. Pp 347-56.

Aaker, J.L., Fournier, S. and Brasel, S.A. (2004), "When good brands do bad". Journal of Consumer Research, Vol. 31. Pp 1-16.

Ailawadi K.L and Keller K.L (2004): "Understanding retail branding: conceptual insights and research priorities". Journal of Retailing, 2004. - No. 80 (4). - pp. 331-342.

Albert. N; Merunka.D and Valette-Florence.P (2008): "When consumers love their brands: Exploring the concept and its dimensions". Journal of Business Research. Vol 61. Pp 1062-1075.

Ambroise. L. (2006) : «La personnalité de la marque : contributions théoriques, méthodologiques et managériales ». Recherche et Applications en Marketing; Vol21, No2. pg96

Ambroise. L. (2006) : «La personnalité des marques : une contribution réelle à leur gestion ? ». Revue Française du Marketing. Vol207. Pp 25-41

Ambroise.L ; Pantin-Sohier.G and Valette-Florence. P. (2007) : «De la personnalité des célébrités à la personnalité des marques : Nouvelle démarche de sélection des ambassadeurs ». Actes du XXIIIème Congrès International de l'AFM - 31 mai \& 1er juin 2007, Aix-les-Bains

Aouini-Mejri. C (2010) : «Les réponses des consommateurs à la qualité sociale des marques de distributeur : Role des variables individuels ». Thèse soutenue à l'Université Paris Est Creteil.

Azoulay. A. and Kapferer. J-N (2003): « Do brand personality scales really measure brand personality ». Brand Management, Vol11, No 2. Pp 143-155.

Becquart. L. (2007) : «Marques de distributeurs, jusqu'ou iront elles?». MDD Rencontres 27/03/07.pp 1-7

Belk R.W. (1988): "Possessions and the Extended Self”. Journal of consumer research. Vol 15. Pp 139-168

Belk R.W. (1990): "The Role of Possessions in Constructing and Maintaining A Sense of past". Advances in Consumer Research. Vol 17. pp 669-676.

Belk. R. W.; Wallendorf.M and Sherry. J.F.(1989) : «The Sacred and the Profane in Consumer Behavior: Theodicy on the Odyssey». The Journal of Consumer Research, Vol. 16, No1.1-38

Bergès-Sennou. F. ; Bontems. P. and Réquillart. V. (2007) : «L'impact économique du développement des marques de distributeurs ». Université de Toulouse. pp1-30

Binninger A.S (2008): "Exploring the relationships between retail brands and consumer store loyalty". International Journal of Retail and distribution management. Vol 36. $\mathrm{N}^{\circ} 2$. pp94-110.

Blythe. J. (2007): «Advertising creatives and brand personality: A grounded theory perspective ». Journal of Brand Management. Vol14, $284-294$.

Boeree. G. (2006): «Personality Theories ». Psychology Department. Shippensburg University, E-book

Brody. R. P and Cunningham. S.M (1986): «Personality variables and the consumer decision process ». Journal of Marketing Research. Vol 5.No1. pp 50-57

Bryan Hayes. J.; Alford. B. L.; Silver.L and York. R P. (2006): « Looks matter in developing consumer-brand relationships » Journal of Product \& Brand Management. Vol $15 \cdot$ No $5 \cdot$ pp 306-31

Burt.S (2000): “The strategic role of retail brands in British grocery retailing”. European Journal of Marketing. Vol34. Nº. Pp875-890.

Capelli. S. and Pantin-Sohier. G (2003) : «Le tempérament de la marque enseigne: Une première étude ». pp1-25

Chaudhuri. A.and Holbrook. M. B (2002): «Product-class effects on brand commitment and brand outcomes: The role of brand trust and brand affect ». Journal of Brand Management; Vol10. No1. Pp 33-58

Churchill. G.A. Jr (1979): “A paradigm for developing better measure of marketing constructs”. Journal of Marketing Research. Vol16. Pp 64-73

Coloigner. T. and Woelfel.G (2001) : «Distribution : les producteurs cherchent leurs marques». Annales des Mines

Corstjens. M and Lal.R (2000): "Building store loyalty through store brands". Journal of marketing research. Vol 73. N³.

Child.P; Heywood.S and Kliger.M (2002): “Do retail brands travel?”.The McKinsey Quarterley. N¹. Pp11-13.

Dabija. D.C (2011): "Producer versus retail brands strategies: positioning vectors in consumers' mind". Mangement and marketing: Challenges for the knowledge society. Vol6. N³. Pp407-420.

Dwayne Ball. A. and Tasaki. L. H. (1992): «The Role and Measurement of Attachment in Consumer Behavior ». Journal of Consumer Psychology. Vol. 1. No2. pp 155-172 
Ferrandi. J-M ; Merunka. D. and Valette-Florence. P. (2003) : «La personnalité de la marque : bilan et perspectives ». Revue française de gestion 2003/4. No 145. Pp 145-162

Filser. M.and Anteblian. B. (1998) : «Marques de producteurs, marques de distributeurs, marques premier prix ». Actes de la 3ème Journée de Recherche en Marketing de Bourgogne. Dijon. Pp 1-187

Fournier S. (1998): "Consumers and their brands: developing relationship theory in consumer research". Journal of Consumer Research. Vol 24. Pp 343-373

Freling. T. H and Forbes. L. P (2005): “An empirical analysis of the brand personality effect”. The Journal of Product and Brand Management; Vol14.No 7. Pp 404-413

Fuat Firat; Dholokia and Venkatesh (1993): "Marketing in a postmodern world”. European Journal of Marketing. Vol29.No1. pp 40-56

Ganesan. S (1994): «Determinants of long term orientation in Buyer-Seller Relationship ». Journal of Marketing, Vol 58, No 2, pp1-19

Geffroy. T et Chabaud.D (2009) : «Les marques de distributeurs au service du pouvoir d'achat : une nouvelle donne ? Papier de recherche $n^{\circ} 61$. Pp1-20.

Gharbi. J- E (2007) : «Théorie Marketing : Le Débat de Fond ». Livre en cours de publication

Gouteron. J. (2006) : «La personnalité de la marque, outil stratégique sur le marché du prêt-à-porter féminin ». La Revue des Sciences de Gestion : Direction et Gestion; No222. pp 47-60

Gouteron. J. (2006) : «L'impact de la personnalité de la marque sur la relation marque-consommateur : Application au marché du prêt-à-porter féminin ». Revue Française du Marketing; No207. Pp 43-59

Grandclément. C (2009): "Le marketing des similarités: les produits à marque de distributeur ». Papier de recherche publié dans Réseaux 24. Pp 221-252

Guyon. H. (2005): “Approche expérimentale de l'influence de la personnalité de marque sur le capital-marque et de ses conséquences en termes de parts de préférence ». Recherche et Applications en Marketing. Grenoble: Sep 2005. Vol. $20, \mathrm{~N}^{\circ} 3$; pp 102-104

Hogan.J; Barrett.P and Hogan.R (2007):“Personality measurement, faking and employment selection”. Journal of Applied Psychology. Vol92. No5. 1270- 1285

Holbrook, M. B and Hirschman, E. C. (1982): "The experiential aspects of consumption: Consumer fantasies, feelings, and fun”. Journal of Consumer Research, 9, 132-140.

Holbrook. M. B. (1993): «Nostalgia and Consumption Preferences: Some Emerging Patterns of Consumer Tastes ». The Journal of Consumer Research, Vol. 20, No.2. pp 245-256

Hoon. S.; Ang E.and Ching Lim.A (2006): "The influence of metaphors and product type on brand personality perceptions and attitudes". Journal of Advertising. Vol. 35, $\mathrm{N}^{\circ}$ 2. Pp 39-50.

Jara.M and Cliquet.G (2007): "Retail brand equity: A conceptual and differentiated approach ». Communication at the 14th EAERCD Conference. Saarbrücken Germany.

Jara.M and Cliquet.G (2009): "Retail brands equity: A PLS approach". European Institute of retailing and services studies. Pp1-39

Jo Bitner. M. (1995): « Building Service Relationships: It's all about promises » Journal of the Academy of Marketing Science. Vo23, No4. Pp 246-251

Kapferer J-N (2004) : «Les marques face au hard discount Quelles stratégies? ». Revue Française de Gestion; Vol 30. 203-210

Kapferer. J.N (1996) "Les marques capital de l'entreprise, les chemins de la reconquête” 2ème edition, Paris, les éditions d'organisation.

Kapferer. J-N (2002): «Reinventing the brand: Can top brands survive the new market realities». Journal of Brand Management; Vol9. No2.481-484

Kassarjian. H. H. (1971): «Personality and Consumer Behavior: A Review ». Journal of Marketing Research, Vol. 8, No. 4. Pp 409-418. Published by: American Marketing Association.

Kessous. A. and Roux. E. (2006): «La nostalgie comme antécédent de l'attachement à la marque ». Papier accepté au 5ème Congrès sur les Tendances du Marketing en Europe, Venise, 20-21 Janvier.

Kitchin. T. (2003): « Corporate social responsibility: A brand explanation ». Journal of Brand Management; Vol10.No 4/5. Pp 312-326

Kleine. R. E. ; Kleine. S. S. and Kernan. J. B. (1993): «Mundane Consumption and the Self: A Social-Identity Perspective ». Journal of Consumer Psychology. Vol. 2. No. 3. Pp 209-235

Kleine. R. E.and Kleine. S. S (1999) : «Consumption and Self-Schema Changes Throughout the Identity Project Life Cycle ». The 1999 Annual Conference of the Association for Consumer Research. Pp 1-23

Kleine. S. S; Kleine. R. E. and Allen. C. T. (1995): «How is a Possession "Me" or "Not Me"? Characterizing Types and an Antecedent of Material Possession Attachment». The Journal of Consumer Research, Vol. 22, No. 3.pp 327-343

Koebel. M. N and Ladwein. R. (1999): «L'échelle de personnalité de la marque de Jennifer Aaker : Adaptation au contexte français » Décision Marketing. $\mathrm{N}^{\circ} 16$. Pp 81-88

Kumar. R.; Luthra. A. and Datta. G. (2006): «Linkages between Brand Personality and Brand Loyalty: A Qualitative Study in an Emerging market in the Indian Context ». South Asian Journal of Management; Vol13.No 1. pp11-35

Larceneux.F et Renaudin .V (2010) : «Une anlyse de l'efficacité des stratégies de labellisation pour les marques des enseignes ». Papier de recherche $\mathrm{n}^{\circ} 2010-16$. Pp1-28.

Levy. S.,J. (1959): «Symbols for sales » Harvard Business Review. Vol37.No4. pp 117-124 
Louis. D. and Lombard. C. (2007): “Impact de la personnalité de la marque sur la satisfaction et la fidélité u consommateur » Papier de recherche. pp1-30

Magali. J. (2004) : «Comparaison des positionnements concurrentiels des marques de distributeurs, selon les perceptions des clients Carrefour et la diffusion effective des magasins». Allocataire de recherche et monitrice en Marketing.

McCracken. G. (1986): «Culture and Consumption: A Theoretical Account of the Structure and Movement of the Cultural Meaning of Consumer Goods ». Journal of Consumer Research, Vol. 13, No. 1.pp71-84. Published by: The University of Chicago Press

Moati.P (2008): “L'envol des marques de distributeurs : une opportunité pour beaucoup d'industriels ». Cahier de recherche Crédoc $\mathrm{n}^{\circ} 242$. Centre de recherche pour l'étude et l'observation des conditions de vie.

Murray. J. B. (2002): “The Politics of Consumption: A Re-Inquiry on Thompson and Haytko's (1997) "Speaking of Fashion”. Journal of Consumer Research, Inc. Vol. 29. Pp 427-440

Nyeck, P, S, 2000 « Typologie d'attitude vis-à-vis du shopping sur web : illustration de la recherche post moderne en marketing »

Okazaki. S. (2005): «Excitement or sophistication? A preliminary exploration of online brand personality ». International Marketing Review Vol. 23 No. 3. Pp 279-303

Opoku. R.; Abratt. R. and Pitt. L. (2006): "Communicating brand personality: Are the websites doing the talking for the top South African Business Schools?" Journal of Brand Management. London. Vol. 14, No 1/2. Pp 20-39

Osler. R. (2007): « The type -role-purpose brand taxonomy ». Journal of Brand Management. Vol14. pp430 - 441.

Pache. G. (2003) : «Les MDD chez Carrefour : une belle histoire et un avenir prometteur ». 5eme Colloque Etienne THIL. La Rochelle.

Pantin-Sohier. G.and Brée. J. (2004) : «L'influence de la couleur du produit sur la perception des traits de personnalité de la marque ». Revue Française du Marketing; Vol196.No1/5. Pp 19-32.

Phau. I. and Lau. K.C. (2001): «Brand personality and consumer self-expression: Single or dual carriageway?" Brand Management. Vol. 8, No. 6. pp 428-444.

Plummer J.T (1984): « How personality makes a difference ». Journal of Advertising Research. Vol24.No6. pp 27-31

Ramaseshan. B.and Tsao.H-Y (2007): « Moderating effects of the brand concept on the relationship between brand personality and perceived quality ». Journal of Brand Management, Vol 14. Pp $458-466$.

Report: "Best retail brands 2012". Interbrand Design Forum

Smaoui. F. (2006) : «La mesure de la personnalité de la marque dans le contexte tunisien : proposition d'une échelle de mesure, premiers résultats ». 4ème colloque International de la Recherche en Marketing Association Tunisienne de Marketing.

Stern. B.B (2006): "What Does Brand Mean? Historical-Analysis Method and Construct Definition". Academy of Marketing Science. Journal. Greenvale: Vol. 34, N 2. Pp 216-223

Thiétart, RA, (2003) : « Méthodes de recherche en management », 2e édition, Dunod, P.216.

Thomson.M; MacInnis. D. J and Whan Park. C (2005): “The Ties That Bind: Measuring the Strength of Consumers' Emotional Attachments to Brands". Journal of Consumer Psychology. Vol. 15, №1. pp 77-91

Tian. K.and Belk. R. W (2005): «Extended Self and Possessions in the Workplace ». Journal of Consumer Research; Vol32.No 2. pp 297-310

Van Gelder. S. (2004): « Global brand strategy». Journal of Brand Management; Vol12, No1. Pp 39-48

Van Rekom. J.; Jacobs. G.and Verlegh. P.W. J. (2006): « Measuring and managing the essence of a brand Personality ». Springer Science and Business Media. Vol17. Pp 181-192

Venkatesh A. (1999): « Postmodernism perspectives for macro marketing: An inquiry into the global information and sign economy » Journal of Macroeconomy, Vol 19. Pp 153-176

Viot. C. (2006): « Personnalité de la marque : La métaphore justifie-elle la transposition d'échelles de personnalité humaine? ».pp $1-29$

Ural.T (2008) : «Factors affecting the success of store brands in Turkish retailing market”. Innovative Marketing, Vol 4.№ 2.

Wallendorf. M. and Arnould. E.J. (1988) : « My favourite things?: Across-cultural inquiry into object attachment, possessiveness and social linkages" Journal of Consumer Research, Vol14, 531-547

Whelan. S. and Wohlfeil. M. (2006): «Communicating brands through engagement with 'lived' experiences ». Journal of Brand Management; Vol13. No4/5; 313-329

Wood. L. (2000): « Brands and brand equity: definition and management » Management Decision. Vol38.No9; 662-669

Annex 1: The qualitative research sample's description

\begin{tabular}{|c|c|c|c|c|}
\hline Respondent & Age range & Sex & Matrimonial Status & Number of children \\
\hline 1 & 20 & Male & Single & 0 \\
\hline 2 & 29 & Female & Married & 0 \\
\hline 3 & 27 & Female & Single & 0 \\
\hline 4 & 20 & Female & Single & 3 \\
\hline 5 & Between 35 and 45 & Female & Married & 0 \\
\hline 6 & Under 25 & Female & Single & 0 \\
\hline 7 & Under 25 & Male & Single & 0 \\
\hline 8 & Between 25 and 35 & Male & Single & 2 \\
\hline 9 & Between 45 and 55 & Female & Married & 0 \\
\hline 10 & Between 25 and 35 & Female & Single & 0 \\
\hline 11 & Between 25 and 35 & Female & Single & 1 \\
\hline 12 & Between 25 and 35 & Female & Married & 0 \\
\hline 13 & Under 25 & Female & Single & 3 \\
\hline 14 & Between 35 and 45 & Female & Married & 2 \\
\hline 15 & Between 45 and 55 & Male & Married & \\
\hline
\end{tabular}


Annex 2: The 64 RBP traits (Output of the qualitative research)

\begin{tabular}{|c|c|c|c|}
\hline Strong & Confident & Deceitful & Original \\
Modest & Reliable & Fresh & Light \\
Masculine & Credible & Happy & Cute \\
Competent & Idle (Lazy) & Pretty & Capricious \\
Imaginative & Feminine & Natural & Refined \\
Tough & Empathetic & Smiling & Classic \\
Archaic & Hard-working & Young & Fascinating \\
Heavy & Creative & Beautiful & Modern \\
Apathetic & Tender & Adorable & Sincere \\
Incompetent & Innovative & Kind & Honest \\
Liar & Clever & Dependent & Soft \\
Flattering & Smooth & Elegant & Optimist \\
Repellent & Cheerful & Unique & Relaxing \\
(unattractive) & Exciting & Imitating & Serious \\
Sympathetic & Charming & Leader & Traditional \\
Successful & Arrogant & Rigid & Old \\
Weak & & & \\
\hline \multicolumn{4}{|l}{}
\end{tabular}

Annex 3: Retailer brands personality: Confirmatory factor analysis

\begin{tabular}{|c|c|c|c|}
\hline Items & Standardized coefficients & Critical ratio & Estimate \\
\hline Beautiful & 0,727 & 7.181 & 1.051 \\
\hline Adorable & 0,690 & 6.831 & 0,981 \\
\hline Cute & 0,778 & 7.680 & 1.027 \\
\hline Optimist & 0,745 & 6.717 & 1.104 \\
\hline Sympathetic & 0,671 & 6.682 & 0,973 \\
\hline Young & 0,584 & 5.839 & 0,882 \\
\hline Pretty & 0,711 & - & 1 \\
\hline Cheerful & 0.671 & 6.225 & 1.161 \\
\hline Happy & 0.816 & 6.692 & 1.393 \\
\hline Smiling & 0.793 & 6.574 & 1.431 \\
\hline Charming & 0.671 & 5.846 & 1.081 \\
\hline Tender & 0.615 & - & 1 \\
\hline Modern & 0.816 & 5.462 & 0.847 \\
\hline Innovative & 0.660 & - & 1 \\
\hline \multicolumn{4}{|c|}{ Absolute indices } \\
\hline $\mathbf{X} 2$ & & \multicolumn{2}{|c|}{93.886} \\
\hline Significance (p-value) & & \multicolumn{2}{|c|}{0,043} \\
\hline DF & & \multicolumn{2}{|c|}{72} \\
\hline GFI & & \multicolumn{2}{|c|}{0,901} \\
\hline AGFI & & \multirow{2}{*}{\multicolumn{2}{|c|}{$\begin{array}{l}0,855 \\
0,052\end{array}$}} \\
\hline RMSEA & & & \\
\hline \multicolumn{4}{|c|}{ Incremental indices } \\
\hline NFI & & \multicolumn{2}{|c|}{0,883} \\
\hline CFI & & \multicolumn{2}{|c|}{0,969} \\
\hline TLI & & \multicolumn{2}{|c|}{0,961} \\
\hline IFI & & 0,9 & \\
\hline \multicolumn{4}{|c|}{ Parsimony indices } \\
\hline PNFI & & \multicolumn{2}{|c|}{0,698} \\
\hline PCFI & & \multirow{2}{*}{\multicolumn{2}{|c|}{$\begin{array}{l}0,767 \\
1.304\end{array}$}} \\
\hline Normed X2 & & & \\
\hline
\end{tabular}

Annex 4: Measurement model of retailer brands personality

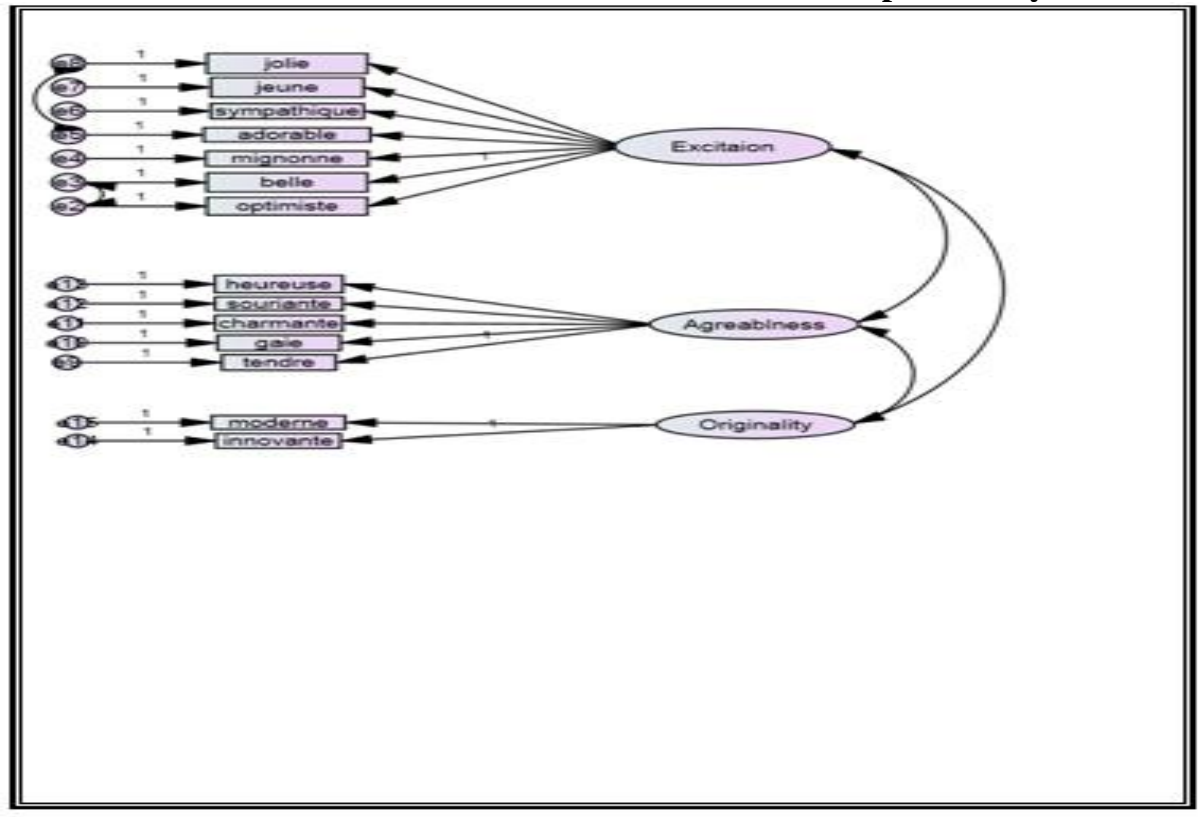

